\title{
SOEP
}

SOEPpapers

SOEPpapers
on Multidisciplinary Panel Data Research

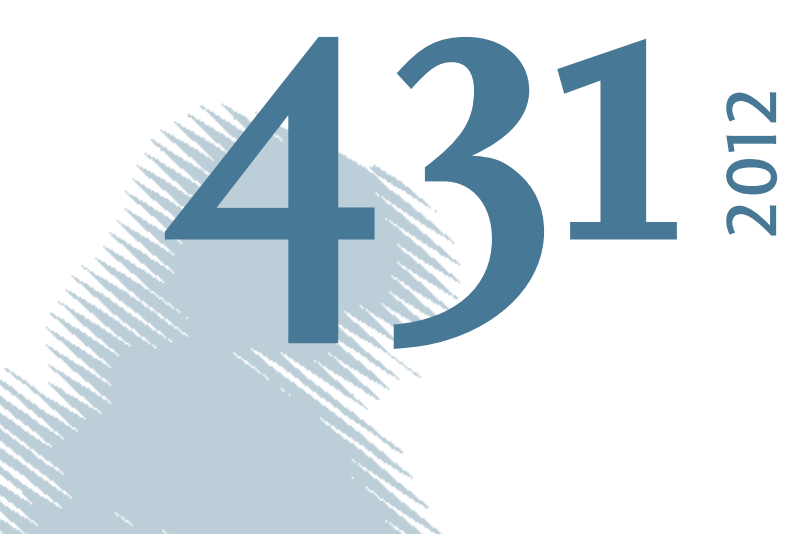

N

\section{Impatience among preschool children and their mothers}

Fabian Kosse, and Friedhelm Pfeiffer 


\section{SOEPpapers on Multidisciplinary Panel Data Research}

at DIW Berlin

This series presents research findings based either directly on data from the German SocioEconomic Panel Study (SOEP) or using SOEP data as part of an internationally comparable data set (e.g. CNEF, ECHP, LIS, LWS, CHER/PACO). SOEP is a truly multidisciplinary household panel study covering a wide range of social and behavioral sciences: economics, sociology, psychology, survey methodology, econometrics and applied statistics, educational science, political science, public health, behavioral genetics, demography, geography, and sport science.

The decision to publish a submission in SOEPpapers is made by a board of editors chosen by the DIW Berlin to represent the wide range of disciplines covered by SOEP. There is no external referee process and papers are either accepted or rejected without revision. Papers appear in this series as works in progress and may also appear elsewhere. They often represent preliminary studies and are circulated to encourage discussion. Citation of such a paper should account for its provisional character. A revised version may be requested from the author directly.

Any opinions expressed in this series are those of the author(s) and not those of DIW Berlin. Research disseminated by DIW Berlin may include views on public policy issues, but the institute itself takes no institutional policy positions.

The SOEPpapers are available at http://www.diw.de/soeppapers

\section{Editors:}

Jürgen Schupp (Sociology, Vice Dean DIW Graduate Center)

Gert G. Wagner (Social Sciences)

Conchita D'Ambrosio (Public Economics)

Denis Gerstorf (Psychology, DIW Research Professor)

Elke Holst (Gender Studies)

Frauke Kreuter (Survey Methodology, DIW Research Professor)

Martin Kroh (Political Science and Survey Methodology)

Frieder R. Lang (Psychology, DIW Research Professor)

Henning Lohmann (Sociology, DIW Research Professor)

Jörg-Peter Schräpler (Survey Methodology, DIW Research Professor)

Thomas Siedler (Empirical Economics, DIW Graduate Center)

C. Katharina Spieß (Empirical Economics and Educational Science)

ISSN: 1864-6689 (online)

German Socio-Economic Panel Study (SOEP)

DIW Berlin

Mohrenstrasse 58

10117 Berlin, Germany

Contact: Uta Rahmann | soeppapers@diw.de 


\title{
Impatience among preschool children and their mothers
}

\author{
Fabian Kosse and Friedhelm Pfeiffer
}

\begin{abstract}
:
Using experimental data of children and their mothers, this paper explores the intergenerational relationship of impatience. The child's impatience stems from a delay of gratification experiment. Mother's impatience has been assessed by a choice task where the mothers faced trade-offs between a smaller-sooner and a larger-later monetary reward with a delay of six or twelve months. The findings demonstrate an intergenerational relationship in short-run decision making. Controlling for mother's and child's characteristics the child's impatience at preschool age is significantly correlated with the six month maternal reservation interest rate.
\end{abstract}

Keywords: time preferences; impatience; intergenerational transmission, field experiments.

JEL classification: C93, D03, D90

Acknowledgements: We would like to thank the Leibniz Association for supporting this study in the research network "Noncognitive Skills: Acquisition and Economic Consequences”. We thank Ernst Fehr, Jürgen Schupp, Katharina Spieß and Gert Wagner for cooperation in the project on mother and child preferences, as well as Pia Dovern-Pinger, Philipp Eisenhauer, Armin Falk, Winfried Pohlmeier, Fabian's colleagues at the BGSE and an anonymous referee for valuable comments. The usual disclaimer applies.

Fabian Kosse, Bonn Graduate School of Economics (BGSE), kosse@uni-bonn.de;

Corresponding author: Friedhelm Pfeiffer, Centre for European Economic Research (ZEW), P.O. Box 103443, 68034 Mannheim, Germany; Phone: ++49 621 1235150;

FAX: ++49 6211235 225; pfeiffer@zew.de. 


\section{Introduction}

Economics studies the intergenerational transmission of skills and optimal human capital investment. Recent research has examined intergenerational associations of cognitive skills (e.g. Black et al., 2008), trust and risk attitudes (e.g. Dohmen et al., 2012), income (e.g. Eisenhauer and Pfeiffer, 2008) and educational attainment (e.g. Björklund et al., 2006, for a summary see also Black and Devereux, 2010).

We contribute to the literature on human capital formation by examining the intergenerational relationship of time preferences among mothers and their children, based on experimental measures of impatience. Impatience is an important parameter in models of human capital investments (e.g. Krebs, 2003), with implications for job search (e.g. Paserman, 2008), credit card borrowing (e.g. Meier and Sprenger, 2010), and many other economic decisions. To the best of our knowledge, our study is the first to examine the intergenerational relationship of impatience based on experimental measures in a sample of preschool children and their mothers (see Bartling et al., 2010).

A common finding is that children become more patient during development (e.g. Bettinger and Slonim, 2007). A potential explanation is that the limbic system, which drives immediate gratification, develops early in life, while the long-run orientated frontal cortex is still developing until the end of teenage age (e.g. Giedd et al., 1999).

Although parent-child interaction is said to be the "cradle of action" (Heckhausen and Heckhausen, 2008: 394) we are not aware of experimental evidence on the intergenerational relationship between impatience among preschool children and their mothers. One may hypothesize that a child's impatience is directly influenced by the mother's impatience through observational learning and thus constitutes an important channel for the intergenerational transmission of human capital.

\section{Dataset and experiments}

A sample of 213 mother-child pairs, who were visited by trained interviewers in their homes is utilized. The sample was taken from a pretest with 291 mother-child pairs for the German Socio-Economic Panel Study (SOEP, see Wagner et al., 2007) performed in 2008, called "Mutter-Kind-Pilot” (Bartling et al., 2010). First, our sample is restricted to children who like gummy bears to ensure incentive compatibility. Second, to control for confounding effects, only biological mothers with German citizenship who breastfed their child and for whom all variables are available, are included. The restrictions reduce the number of observations to 213. 
The experimental setting concerning the children's patience is an adaption of the delay of gratification experiments by Mischel et al. (1989). In our setting the interviewer opened a bag of gummy bears and explained that the child could either eat them now or wait until the end of the mother's interview and receive an additional bag. Thus, children were faced with the decision between receiving a smaller reward (one bag of gummy bears) sooner, or waiting and receiving a larger reward (two bags of gummy bears) later. $22.1 \%$ of the children took the opened bag before the interview ended. They are classified as impatient. $77.9 \%$ waited and received two bags of gummy bears. They are classified as patient.

Concerning the mothers' impatience a classical choice task was used where the mothers faced a table of trade-offs between a smaller-sooner and a larger-later monetary reward (e.g. Dohmen et al., 2010). They had to decide between a fixed amount of $100 €$, available without a delay, or a higher amount, available after a delay. All mothers went through two versions of the experiment, the first with a delay of six months and the second with a delay of twelve months. Incentive compatibility was implemented by a 1-in-7 chance that the participant received the result of one randomly selected decision. The larger-later reward started with $100 €$ plus $2.5 \%$ p.a. and increased successively by $2.5 \%$ p.a. but at most 19 times. After the first choice of the larger-later reward, the participant was informed that it was assumed that she also prefers all higher delayed rewards. This design slightly deviates from Dohmen et al. (2010).

The successive increase of the larger-later amount reveals the interval at which the mother is indifferent to receiving the smaller-sooner or the larger-later reward. The middle of this interval is used as a proxy for the value of indifference. Lower or upper bounds of the indifference values are obtained for those mothers who either always preferred the delayed or always preferred the non-delayed reward. These censored observations have been either used directly or have been replaced by their conditional expectation from Tobit estimates, using a set of available socio-economic variables and survey questions.

A short-run reservation interest rate (SIR) is calculated based on the indifference value concerning the six-month delay and a medium-run reservation interest rate (MIR) based on the indifference value concerning the twelve-month delay. Concerning both measures, an annual interest rate has been calculated assuming semi-annual compounding. The mean and standard deviation has been computed including the conditional expectations from Tobit estimates for the censored observations. We yield a mean (standard deviation) for SIR of $37.3 \%$ p.a. (24.0\% p.a.) and for MIR of $30.3 \%$ p.a. (20.3\% p.a.). These average reservation interest rates for adults are relatively high, a finding not uncommon in experiments (Frederick et al., 2002). 


\section{Exploring the intergenerational relation of impatience}

If there is an intergenerational relation, an impatient mother could be expected to have a higher probability of having an impatient child. Since the delay of gratification experiment reflects a short-run decision, we expect particularly the mothers' short-run reservation interest rate to be related to the child's impatience. To explore this relation, we performed Probit analyses, with the child's impatience as the dependent variable and the mother's (standardized) reservation interest rate and several controls as right-hand variables (Table 1).

Table 1 demonstrates that a higher value of mother's SIR (more impatience) is associated with a higher probability that her child cannot delay the gratification (is impatient) (column 1). The inclusion of child and mother characteristics increases the relationship slightly (column 2). Child and mother characteristics contribute to explaining impatience. For instance, older aged children and children with a higher weight at birth have a lower probability of being impatient, which seems to be in line with the literature (e.g. Bettinger and Slonim, 2007). These results are available upon request.

If censored observations are replaced by their conditional expectations, results do not change much (column 3). An increase of one standard deviation (24.0\% p.a.) of mother's SIR evaluated at sample means increases the probability that the child is impatient by about $6.8 \%$ $(p=.033$ ) (estimates from column 3). The correlation concerning mother's MIR (columns 4, 5 and 6 in Table 1) is also positive but measured only with a low degree of precision.

To sum up, the findings demonstrate an intergenerational relationship in short-run decision making. Mother's and child's impatience, an important part of human capital, are correlated when the child is at preschool age. More research is necessary to highlight intergenerational transmission also in longer-run decision making. 


\section{References}

Bartling, Björn, Ernst Fehr, Barbara Fischer, Fabian Kosse, Michel Maréchal, Friedhelm Pfeiffer, Daniel Schunk, Jürgen Schupp, Katharina Spieß, and Gert Wagner. 2010. "Geduld von Vorschulkindern - Ergebnisse einer Experimentalstudie im Haushaltskontext von Kindern.“ Schmollers Jahrbuch - Journal of Applied Social Science Studies. 130(3): 297-324.

Black, Sandra and Paul J. Devereux. 2010. "Recent Developments in Intergenerational Mobility.” NBER Working Paper \# 15889, Cambridge.

Black, Sandra E., Paul J. Devereux, and Kjell G. Salvanes, 2009. "Like father, like son? A note on the intergenerational transmission of IQ scores.” Economics Letters 105 (1), 138140.

Bettinger, Eric and Robert Slonim. 2007. "Patience among Children." Journal of Public Economics, 91(1-2): 343-363.

Björklund, Anders, Mikael Lindahl, and Erik Plug. 2006. "The Origins of Intergenerational Associations: Lessons from Swedish Adoption Data." Quarterly Journal of Economics, 121(3): 999-1028.

Dohmen, Thomas J., Armin Falk, David Huffman, and Uwe Sunde. 2010. "Are Risk Aversion and Impatience Related to Cognitive Ability?” American Economic Review, 100(3): 1238-1260.

------ 2012 . "The Intergenerational Transmission of Risk and Trust Attitudes.” The Review of Economic Studies, Advance Access published November 2011, doi: 10.1039/restud/rdr027.

Eisenhauer, Philipp and Friedhelm Pfeiffer. 2008. "Assessing Intergenerational Earnings Persistence among German Workers.” Journal of Labour Market Research, 41(2-3): 119137.

Frederick, Shane, George Loewenstein, and Ted O'Donoghue. 2002. "Time Discounting and Time Preference: A Critical Review.” Journal of Economic Literature 40(2): 351-401.

Giedd, Jay N., Jonathan Blumenthal, Neal O. Jeffries, F. X. Castellanos, Hong Liu, Alex Zijdenbos, Tomáš Paus, Alan C. Evans, and Judith L. Rapoport. 1999. "Brain Development during Childhood and Adolescence: A Longitudinal MRI Study" Nature Neuroscience, 2(10): 861.

Heckhausen, Jutta and Heinz Heckhausen. 2008. "Motivation and Development." In: Jutta Heckhausen and Heinz Heckhausen (eds.). Motivation and Action, Cambridge, Cambridge University Press, 384-443.

Krebs, Tom. 2003. "Human Capital and Economic Growth." Quarterly Journal of Economics, 118(2): 709-744.

Meier, Stephan and Charles Sprenger. 2010. "Present-Biased Preferences and Credit Card Borrowing.” American Economic Journal: Applied Economics, 2(1), 193-210.

Mischel, Walter, Yuichi Shoda, and Monica Rodriguez. 1989. "Delay of Gratification in Children.” Science, 244: 933-938.

Paserman, Daniele. 2008. "Job Search and Hyperbolic Discounting: Structural Estimation and Policy Evaluation.” The Economic Journal, 118(531): 1418-1452.

Wagner, Gert G., Joachim R. Frick, and Jürgen Schupp. 2007. “The German SocioEconomic Panel Study (SOEP) - Scope, Evolution and Enhancements.” Schmollers Jahrbuch 127 (1), 139-169. 
1: Impatient Child

(1) (2) (3) (4) (5) (6)

\begin{tabular}{lccccccc}
\hline Standardized SIR (6 months delay) & $.052^{*}$ & $.069^{* *}$ & $.068^{* *}$ & & & \\
& $(.030)$ & $(.033)$ & $(.032)$ & & & \\
Standardized MIR (12 months delay) & & & & .031 & .039 & .038 \\
& & & & $(.028)$ & $(.032)$ & $(.032)$ \\
Child Characteristics & No & Yes & Yes & No & Yes & Yes \\
Mother Characteristics & No & Yes & Yes & No & Yes & Yes \\
Censored IR predicted & No & No & Yes & No & No & Yes \\
\hline Observations & 213 & 213 & 213 & 213 & 213 & 213 \\
McFadden's Pseudo R-squared & .014 & .140 & .140 & .005 & .125 & .125 \\
\hline \hline
\end{tabular}

The dependent variable is one for impatient children and zero for patient children. Reservation interest rates refer to experimentally revealed indifference points and are standardized (mean=0, standard deviation=1). Controls concerning the child are age, age squared, sex, birth weight, the duration of breastfeeding, and dummies indicating the point in time since the last bigger meal. Controls concerning the mother are age, age squared and dummies indicating house ownership and whether the child has to share his room, both serving as proxies for wealth. The reported coefficients are average marginal effects evaluated at sample means; bootstrapped standard errors in parentheses (10,000 replications); ** (*) indicates significance at the 5\% (10\%) level. 